\title{
Quantitative comparison of 2D and 3D late gadolinium enhancement MR imaging for cardiomyopathies
}

\author{
Fabian Morsbach ${ }^{1 *}$, Sonja Gordic ${ }^{1}$, Robert Götti ${ }^{1}$, Markus Niemann², Hatem Alkadhi', Gruner Christiane ${ }^{2}$, \\ Robert Manka
}

From 17th Annual SCMR Scientific Sessions

New Orleans, LA, USA. 16-19 January 2014

\section{Background}

LGE is widely used as a means to quantify scar or fibrotic tissue in patients suffering from cardiomyopathies. In clinical routine $2 \mathrm{D}$ data acquisition is most commonly practiced, albeit having the drawback of multiple breath-holds and long acquisition times. 3D acquisition can significantly reduce acquisition time. This leads to shortened scan time and a more efficient use of available MRI resources. So our purpose was to determine whether the quantification of myocardial fibrosis in patients with Fabry disease and hypertrophic cardiomyopathy ( $\mathrm{HCM})$ using a late gadolinium enhancement (LGE) single-breath-hold threedimensional (3D) inversion recovery magnetic resonance (MR) imaging sequence is comparable with a clinically established two-dimensional (2D) multi-breath-hold sequence.

\section{Methods \\ 40 consecutive patients ( 18 men; mean age $50 \pm 17$ ) with either Fabry disease $(n=18)$ or HCM $(n=22)$ were enrolled in this prospective study. Studies were conducted on a 1.5-T clinical MR imaging system. Spatial resolution was the same for $3 \mathrm{D}$ and $2 \mathrm{D}$ images (field-of-view, $350 \times 350 \mathrm{~mm} 2$; in-plane-resolution, $1.2 \times 1.2 \mathrm{~mm} 2$; section-thickness, $8 \mathrm{~mm}$ ). Datasets were analyzed for subjective image and quantitative evalua- tion of myocardial mass (grams), fibrotic mass (grams) and total fibrotic tissues percentage. Statistical analysis included Wilcoxon-signed-rank test, student's t-test for paired samples and Bland-Altman analysis.}

${ }^{1}$ Institute for Diagnostic and Interventional Radiology, University Hospital Zurich, Zurich, Switzerland

Full list of author information is available at the end of the article

\section{Results}

There was no significant difference in subjective image quality between acquisitions $(P>0.1)$ for either disease. In patients with Fabry disease there was no significant differences in myocardial mass between 3D (100.7 $\mathrm{g} \pm$ $30.8 \mathrm{~g}$ ) and $2 \mathrm{D}$ acquisition $(99.9 \mathrm{~g} \pm 31.9 \mathrm{~g}$; $\mathrm{P}=0.55)$, as well as for fibrous tissue mass $(3.9 \mathrm{~g} \pm 6.4 \mathrm{~g}$ vs $4.0 \pm 6.4 \mathrm{~g}$; $\mathrm{P}=0.89)$ and total fibrous percentage $(3.4 \% \pm 5.5 \%$ vs $3.4 \pm 5.5 ; \mathrm{P}=0.89)$. Bland-Altman analysis showed good agreement between $3 \mathrm{D}$ and $2 \mathrm{D}$ datasets for myocardial mass(mean difference: $0.8 \mathrm{~g}$; limits of agreement: $-10.2 \mathrm{~g}$ - $11.8 \mathrm{~g}$ ), fibrous tissue mass (mean difference: $-0.02 \mathrm{~g}$; limits of agreement: $-1.45 \mathrm{~g}-1.41 \mathrm{~g}$ ), total fibrous percentage (mean difference:0.02\%; limits of agreement: -1.31\%$1.35 \%)$. In patients with HCM there was no significant differences in myocardial mass between 3D (115.5 $\mathrm{g} \pm$ $33.3 \mathrm{~g}$ ) and $2 \mathrm{D}$ acquisition (116.7 $\mathrm{g} \pm 33.6 \mathrm{~g} ; \mathrm{P}=0.48)$, as well as for fibrous tissue mass $(5.6 \mathrm{~g} \pm 8.6 \mathrm{~g}$ vs $5.7 \mathrm{~g} \pm 8.7 \mathrm{~g}$; $\mathrm{P}=0.6)$ and total fibrous percentage $(4.3 \% \pm 6.4 \%$ vs $4.3 \% \pm 6.5 \% ; \mathrm{P}=0.89$ ). Bland-Altman analysis showed good agreement between 3D and 2D datasets for myocardial mass (mean difference: $-1.2 \mathrm{~g}$; limits of agreement:-16.1 $\mathrm{g}$ $13.7 \mathrm{~g}$ ), fibrous tissue mass (mean difference $-0.08 \mathrm{~g}$; limits of agreement: $-1.33 \mathrm{~g}-1.17 \mathrm{~g}$ ), total fibrous percentage (mean difference:-0.01 g; limits of agreement:-1.01 g-0.99 g). Acquisition time was significantly shorter for $3 \mathrm{D}$ sequences (24.9 seconds \pm 5.2 seconds) as compared to $2 \mathrm{D}$ sequence (349.1 seconds \pm 62.3 seconds, $\mathrm{P}<0.001$ ).

\section{Conclusions}

3D LGE imaging enables comparable quantification of fibrous myocardial tissue compared to a $2 \mathrm{D}$ sequence at a faster acquisition rate. 


\section{Funding}

Nothing to disclose.

\section{Authors' details}

${ }^{1}$ Institute for Diagnostic and Interventional Radiology, University Hospital

Zurich, Zurich, Switzerland. ${ }^{2}$ Cardiology Clinic, University Hospital, Zurich,

Switzerland

Published: 16 January 2014

doi:10.1186/1532-429X-16-S1-P330

Cite this article as: Morsbach et al:: Quantitative comparison of 2D and

3D late gadolinium enhancement MR imaging for cardiomyopathies.

Journal of Cardiovascular Magnetic Resonance 2014 16(Suppl 1):P330.

Submit your next manuscript to BioMed Central and take full advantage of:

- Convenient online submission

- Thorough peer review

- No space constraints or color figure charges

- Immediate publication on acceptance

- Inclusion in PubMed, CAS, Scopus and Google Scholar

- Research which is freely available for redistribution

Submit your manuscript at www.biomedcentral.com/submit
Ciomed Central 